"Exploring alternative theories of economic regionalism: From trade to finance in Asian co-operation"

Heribert Dieter and Richard Higgott

CSGR Working Paper No. 89/02

January 2002
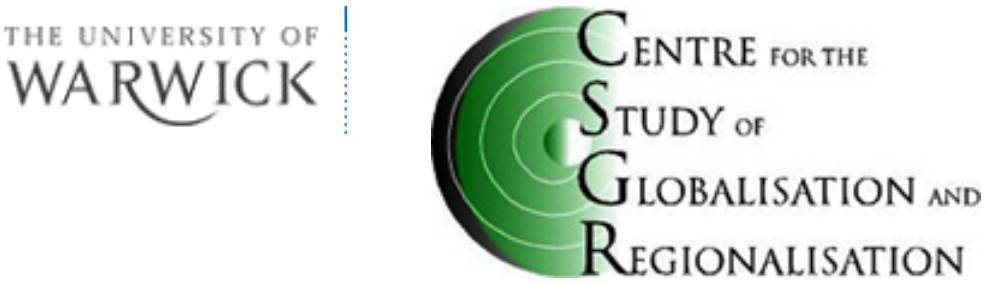


\title{
Exploring alternative theories of economic regionalism: From trade to finance in Asian co-operation
}

Heribert Dieter and Richard Higgott ${ }^{1}$

German Institute for International and Security Affairs and CSGR, University of Warwick CSGR Working Paper No

January 2002

\begin{abstract}
The financial crises of the late 1990s marked an intellectual watershed for the global economy, and also for regionalism as the Janus face of globalisation. At the beginning of the $21^{\text {st }}$ century, the theory and practice of regional cooperation and integration may evolve along different lines to how it was understood for most of the second half of the $20^{\text {th }}$ century. In East Asia, in particular, this will mean that the relationship between multilateralism and regionalism will change. The 'East Asian' region will become an increasingly important domain within which to explore enhanced protection against financial crises. What we might call 'monetary regionalism', sceptical western voices notwithstanding, is now firmly on the regional agenda in East Asia.

Within conventional political economy, the theory and practice of monetary regionalism is not as easy to understand as traditional trade driven regional integration. Thus one aim of this paper is to outline a theory of monetary regionalism and demonstrate the degree to which it represents a sharp break with understandings of the regional project that pertained in East Asia prior to the late 1990s.

From its start in 1989, APEC claimed to be a new type of regionalism. The promise was that APEC would promote open regionalism, i.e. the development of an approach to regional integration that would not harm the multilateral trading order. APEC, despite substantial peer pressure, did not achieve this goal. That APEC played any significant role in the advancement of regional trade integration cannot be proven. What can be said, however, is that it provided no support to its Asian members during the financial crises of the late 1990s.

At the same time, more traditional (what we might call Balassian) understandings of trade driven regional integration are not showing any sign of decreasing importance, To the contrary, there is a growing appeal of trade co-operation, notably an increasing interest in bilateral preferential trading arrangements. This leads to a complex picture of competing regional initiatives across the economic policy spectrum. The paper locates these initiatives in the wider context of the growing politico-economic dialogue between Southeast and Northeast Asia that has developed via the ASEAN+3 process since 1997 .
\end{abstract}

Key words: East Asia; regional cooperation; monetary regionalism

\section{Address for correspondence}

Centre for the Study of Globalisation and Regionalisation

University of Warwick

Coventry, CV4 7AL, UK

\footnotetext{
1 *Heribert Dieter is Senior Research Associate, German Institute for International and Security Affairs, Berlin and Associate Fellow, Centre for the Study of Globalisation and Regionalisation, University of Warwick. Contact: heribert.dieter@swp-berlin.org.
}

Richard Higgott is Professor and Director, UK Economic and Social Science Research Council Centre for the Study of Globalisation and Regionalisation, University of Warwick and Editor, The Pacific Review.

Contact: Richard.Higgott@warwick.ac.uk. 


\section{Introduction}

East Asia is a region of economic experimentation. The financial crises of the late 1990s forced regional scholars and policy makers alike to examine not only their national economic policies, but also their very understanding of regionalism. Frustration with the prevailing orthodoxy of trade driven understandings of regionalism can be witnessed throughout East Asia. Conventional approaches do not address the major concern of regional policy makers, namely financial volatility. While the crises of the late 1990s exposed the weaknesses of existing regional institutional economic arrangements - from ASEAN through to APEC - one by-product of the period of crisis has been an increased willingness to see the longer term importance of enhanced economic policy co-ordination for all states of the region. This, however, is developing not at the lower regional level of ASEAN, nor at the mega Pacificwide level of APEC. But rather, through one set of lenses at least, interest now focuses on what looks like the most obvious understanding of region: that of East Asia combining ASEAN with the major states of Northeast Asia, China, Japan and South Korea.

Perhaps the main lesson of the Asian crises of the late 1990s is that the failure of regional economic co-operation at the end of the $20^{\text {th }}$ century appears to have led to a diminution of economic policy autonomy for many states of the region. Paradoxically, however, it is a speculation of this paper that this threat could result in a greater commitment to pooling some sovereignty in the monetary area (especially for the smaller states) in aspiration of longerterm regional stability.

Before the crisis, regionalism in the Asia-Pacific was trade led and had been driven by the Caucasian members of APEC. This approach, however, now seems less salient. When the going got tough in the late 1990s, APEC lost its attractiveness for the Asian players in particular. It offered too little with regard to reducing financial instability, and expected too much with regard to increasing US demands for 'open sectoralism' in trade relations (Aggarwal and Ravenhill 2001).

Asian policy communities have learned that globalisation and regionalisation are not mutually exclusive activities but rather they exist in a dialectical relationship (Higgott, 1997a). The 'new regionalism' (see Gamble and Payne, 1996) is not an alternative to globalisation. Rather, it is an ineluctable part of it. Less a challenge to multilateralism, the new regionalism 
represents a meso level in an emerging structure of multi-level governance geared to fostering cooperation and trade creation. ${ }^{2}$

Following the logic of this argument allows us to explain the emergence of a multiplicity of policy responses to recent economic issues in the Asia-Pacific. For the purpose of this paper it is becoming obvious that there is more than one way to regionalism. For too long, much of the theoretical literature has held up the development of the EU as but the only approach (see Breslin and Higgott, 2000.) Increasingly, we can witness Asian resistance to western driven models. Trade policy in the region operates at all levels--bilateral, regional and multilateral-with bilateralism currently dominant in trade relations for several states of the region.

By contrast, monetary regionalism is proving, rhetorically at least at this stage, as an increasingly popular avenue of investigation in the region. The traumatic experience of the Asian crisis, ergional preceptions of humiliation by the West and piecemeal progress in IMF reform has encouraged the emergence of an agenda for enhanced monetary cooperation. Rather than waiting for a fundamental reform of the international financial architecture, Asia has started to look at the question regionally.

The paper proceeds in three parts. Part 1 outlines the traditional understanding of regional economic integration, notably in the work of Bela Balassa and introduces, as a possible alternative, the notion of 'monetary regionalism'. Monetary regionalism provides a theoretically plausible and potentially beneficial option for East Asia. ${ }^{3}$ It may, we argue, be able to offer solutions that conventional regionalism has not been able to provide. Conventional regionalism is based on trade integration and does not increase the monetary and financial linkages between participating economies until they reach a high level of integration. It took the European Union more than 40 years until such a level was reached and a common currency could be created. ${ }^{4}$ In the meantime, the countries participating in a conventional integration project do not enjoy protection against financial crises. Neither with regard to the stabilisation of the exchange rate of their currencies, nor with regard to the

\footnotetext{
2 However, whether the mushrooming of regional trade agreements will weaken the World Trade Organisation WTO is not clear yet.

3 Throughout this paper, the term region is used for supranational, not sub-national, regions.

4 However, the creation of the European Monetary System in 1979 provided a starting point for monetary cooperation in Europe. Therefore, before the creation of the Single Market by 1992 first steps of monetary integration were implemented prior to the completion of level 3 of Balaassa's typology (see Apel 1998; Eichengreen 2000; James 1996).
} 
stabilisation of capital flows do conventional integration schemes strengthen the economies of member states.

The current economic crisis in Argentina underlines the weakness of conventional regional integration. In 1991, Argentina, Brazil, Paraguay and Uruguay founded the Mercosur. This (incomplete) customs union enabled the rapid expansion of regional trade. For example, from 1992 to 1997 Argentinean exports to Brazil rose form $\$ 1.7$ billion to 7.8 billion. But the incompatibility of exchange rate policies then played a major role in the collapse of the economy of Argentina. When Brazil had to abandon its peg to the US-Dollar in early 1999, the Real declined steeply, whilst Argentina maintained its currency board with the Dollar. Argentinean exporters suffered a severe blow to their competitiveness, and the downward spiral of the economy began. Conventional, trade-based regionalism offers no solutions to this type of problem.

The improvement of the existing multilateral institutions, in particular of the International Monetary Fund (IMF), would be an alternative to monetary regionalism. But this does not seem overly plausible. The IMF continues to be an institution which suffers from too much influence of the American Treasury and Wall Street and whose policies frequently result in doubtful results, in particular in East Asia and Russia. It continues to be primarily a creditor cartel. The IMF is, of course, no stranger to criticism (not all of it fair it has to be said), but the significance of criticism since 1997 is that it comes not only from radical opponents, but also from impeccably credentialled economists, most notably, but not exclusively, the former Chief Economist of the World Bank and winner of the Nobel Prize for Economics, Joseph Stiglitz (2000). He, along with others, such as Paul Krugman and Dani Rodrik, has provided a telling critique of IMF policies during the crisis in Asia as well as in the process of Russia's transformation. At his most strident, Stiglitz accused the IMF of implementing the wrong policies and being an institution that lacked both democratic structures and able economists. Stiglitz asked:

'Most importantly, did America and the IMF push policies because we, or they, believed the policies would help East Asia or because we believed the would benefit financial interests in the United States and the advanced industrial world?' (Stiglitz 2000, p. 10). 
The answer to the question is less significant than the perception that it captures. For the states of East Asia, the latter proposition was believed, in many sections or the regional policy community, not to be without foundation. One impact of this perception, discussed in Part 2, demonstrates the decreasing importance of conventional regionalism in East Asia and identifies two seemingly paradoxical counter trends. On the one hand is the new interest in monetary regionalism and, on the other, a renewed interest in bilateral free trade, or more precisely preferential trade, initiatives to bolster existing WTO style commitments while reflecting a decreasing importance in the APEC style trade regional agenda of the 1990s.

Part 2 also discusses the theoretical implications of these different initiatives. What do they tell us about regionalism in East Asia at the beginning of the $21^{\text {st }}$ century? At the very least, bilateral trade agreements reflect the absence of a dominant and agreed intellectual and policy strategy in the region. These initiatives demonstrate a time of intellectual curiosity and policy uncertainty. They are part and parcel of a trend that has gained momentum since the financial crises of the late 1990s, the backlash against the WTO since the so-called 'Battle of Seattle' and the more general questioning of the neo-liberal agenda in the developing world in late $20^{\text {th }}$ century (Higgott 2000; Higgott and Phillips, 2000).

These issues are generated not only within the regional policy communities, but also externally. The return to unilateral policy across a range of areas in on US foreign policy and the destabilising effect that this has had on the international trade agenda are salient factors here. Nowhere is this better illustrated than in a growing US recourse to 'open sectoralism' in trade policy.

Section 3 looks at contemporary policies and issues, especially the changing nature of Japanese policy towards questions of regional monetary co-operation. This reflects an important 'mood swing' in Japanese foreign economic policy reflecting the acceptance of the need for a greater regional leadership role, albeit but one contrained by the new realities of Japanese econmic life in the late $20^{\text {th }}$ and early $21^{\text {st }}$ centuries.

Section three also addresses the 'new regionalism' and especially the role played by China and Japan. China's participation in the Chiang Mai initiative underlines the willingness to assume regional leadership. Prime Minister Zhu Rongii's proposal in November 2000 for an ASEAN /China free trade area shows yet another dimension of emerging Chinese policy. The decision to start negotiations on this project, taken by China and the ASEAN countries in 
November 2001, underlines the growing acceptance of China as a leading power in East Asia. Without underestimating the continuing role of the US in the region, it is quite clear that as the $21^{\text {st }}$ century progresses, successful regional policy coordination will be as much dependent on Sino-Japanese relations and leadership as on US relations with these two states, either singularly or collectively..

Finally, the paper examines the obvious lack of comprehension, appeciation and the absence of a clear policy position by the US vis-à-vis contemporary East Asian regionalism. Despite the fact that no single country enjoys the status of a hegemonic power, both the US and Japan have the power to bloc each other's initiatives. As David Rapkin (2001) shows, while the US prevented the creation of an Asian Monetary Fund in 1997, Japan, in similar fashion has successfully obstructed the implementation of a US driven desire for 'Early Voluntary Sectoral Liberalisation' in APEC. Thus both the US and Japan have blocking power, but neither is in a position to provide positive hegemonic leadership. This is an important reality for the future of the regional agenda in Asia in the coming years. The paper concludes by preempting some anticipated criticisms of its core propositions.

The method adopted in this paper is in need of a brief comment. In keeping with much theorising in economics it attempts to advance a speculative, normative and forward-looking position on a particular issue; namely that monetary regionalism is a theoretically possible proposition in East Asia. The paper does not argue the inevitablility of the development of monetary regionalism in Asia rather than its theoretical plausibility. In this regard the paper is deductive. But to the extent that the theoretical possiblility of monetary regionalism is grounded in a the narrative of contemporary East Asian economic diplomacy, the paper, inkeeping with much international relations, is also an exercise in plausible induction. This approach has both strengths and weaknesses. It is unlikely to be sufficiently theoretical for a mainstream economic theorists of integration (especially minus any algebra). Nor is it likely to be sufficiently historically embedded for the more narrative driven scholarship of many scholars of international relations on the other. But, and this is the innovative strength of the paper we would wish to argue, to the extent that it attempts to marry the deductive methodology of economics with the inductive analysis of international relations and political science it is an attempt at a exercise in appropriate contemporary international political 
economy befitting a journal like RIPE. ${ }^{5}$ True to the title of the paper, it is an exercise in (normative) exploration.

\section{(1) The Economics of Regional Integration}

\section{The Empirical Limits of ASEAN and APEC.}

The events in 1997 and 1998 have contributed to the evolution of a new type of regionalism in Asia. The existing regional integration projects, in particular the Association of Southeast Asian Nations (ASEAN and AFTA) and the Asia-Pacific Economic Cooperation (APEC) have had a diminished role in this period. Indeed, the limits of ASEAN underlines the inability of conventional, trade-based integration systems to avoid the emergence of financial crises and to limit their intensity. Although ASEAN is one of the oldest regional integration projects, and has been in operation for more than three decades, it had nothing to offer in 1997. Neither liquidity, nor even good advice, were provided. ${ }^{6}$ Instead, two ASEAN countries, Thailand and Indonesia, had to call the IMF to the rescue. ASEAN emerged damaged from the crisis (Higgott, 1998, Camroux 2001; Rüland 2000) and its vision--the establishment of a free trade area and the continuation of its low key approach to regional integration--problematic. Although regional policy makers would not state it, it seems in many quarters that the benefits from this type of supranational regionalism are deemed too limited to warrant other than minimum effort. Successful exporters to world markets can expect very few advantages from the creation of a free trade area in their region. ${ }^{7}$

Furthermore, the implementation of AFTA is a complicated affair. For example, Malaysia insists on the protection of its internal car market for the Proton, while Thailand needs free regional trade in cars to attract foreign investment. Any such deadlock is hard to resolve. Moreover, Webber identifies problems for ASEAN in policy domains other than trade and finance. Notably, the coup in Cambodia, the 'haze crisis' in maritime Southeast Asia caused by huge forest fires in various parts of Indonesia and the crisis in East Timor-placed major

\footnotetext{
${ }^{5}$ Higgott has tried to advance the case for an approach to IPE in which students of economics and international relations genuinely engage, rather than simply sniping at each other for there lack of worldliness on the one hand or theoretical abstraction on the other. (see Higgott, 2002).

6 Before March 1997, ASEAN finance ministers had never met officially. When they came together for the first time in Phuket, controversial issues were not debated (Rüland 2000, p. 428).

7 Two reservations have to be made: Firstly, the creation of a free trade area of sufficient size may encourage direct foreign investment. Secondly, the establishment of a free trade area with one of the poles of the global economy, e.g. between South Africa and the European Union, can in fact bring substantial benefit to the participating developing economy.
} 
strains on a weakened ASEAN (Webber 2001, 350). As Ruland notes $(2000,444)$ it is hard not to draw the conclusion that ASEAN represents fair weather co-operation that flourishes under the conditions of economic boom, but not in a crisis.

For APEC, the Asian crisis that started in July 1997 has contributed to its decline. The failure of APEC to provide any meaningful response to the biggest economic crisis in the AsiaPacific region since 1945 made this project seem less important, if not irrelevant, for many Asian members. As in the case of ASEAN, not even good advice was provided. The two APEC Summits that could have proposed solutions to the crisis, the 1997 meeting in Vancouver and the 1998 meeting in Kuala Lumpur, were not able to provide the hint of an alternative rescue package for the affected countries. The Vancouver meeting only endorsed the IMF's policies. ${ }^{8}$ Which with hindsight, appeared to drive the region deeper than necessary into crisis and contributed little to its solution (see Dieter 1998 and Higgott 1998).

It can be claimed that APEC has been blamed unfairly (pace Ravenhill 2000, p. 326). The control of financial volatility was never part of its remit. More positively, Harris argues that the fact that the Asian crisis did not result in a protectionist surge in the region should be credited to APEC:

Given the limited role APEC could be expected to play directly, the hope was initially that APEC could hold the line in the trade field in the face of the downturn; to resist the pressure on countries to turn inward and protect individual domestic markets and producers. Contrary to a wide expectation at the time, the line was held - and indeed in a number of countries, further liberalisation has taken place" (Harris 2000, p. 13).

Notwithstanding that Harris identifies only a correlation rather than offering a proof of causation, the crisis underlined APEC's status as a mere dialogue scheme. Moreover, this analysis did not anticipate the recent surge in bilateral trade initiatives. APEC might be a forum in which members of a heterogeneous region might talk, but it does not represent a case of actual regional integration, or indeed major regional policy coordination. Moreover, it is not clear why a protectionist backlash should have been expected in the first place. The countries in crisis were confronted with a sudden shortage of capital, not with an inflow of goods from other countries. The only APEC countries that can claim to have eased the crisis

8 The Leaders' Declaration discussed the financial crisis, but the suggested regional responses were limited to surveillance and improved regulatory capacities. With regard to crisis prevention on the global level, the IMF's importance was underlined: "We believe it is critically important that we move quickly to enhance the capacity of the international system to prevent or, if necessary, to respond to financial crises of this kind. On a global level, the role of the IMF remains central" (APEC Leaders' Declaration, 25 November 1997, Vancouver). 
by not raising the barriers to imports were the USA, Canada and to a lesser degree Australia. Even then, it is hard to see a positive influence of the APEC process on policy makers at the time. The policy choice to keep American markets open was made, but not because Congress or the Clinton administration wanted to strengthen APEC.

Increasingly, Asian observers tend to evaluate APEC as a tool of American foreign economic policy. ${ }^{9} \quad$ APEC has not been, nor was it ever likely to be, successful in creating a joint identity as the basis for further co-operation (Higgott 1994) and, increasingly, the lack of tangible benefits has been progressively criticised (Ravenhill 2000). At the November 2000 summit the major concern amongst leaders was what might be done to stem the backsliding that was taking place on earlier commitments. But the decline of commitment to APEC was not simply a product of those states most adversely affected by the financial crises turning their backs on the organisation. The major states too demonstrated diffidence to its well being. Japan was at the forefront of the opposition to US attempts to advance a sectoral approach to liberalisation. In turn, the Clinton administration's loss of control of its domestic agenda saw it take its foot off the global liberalisation accelerator.

In sum, APEC's decline has been caused by its inability to foster the development of a panPacific economic community. Its concentration on facilitating contacts between business people in the corporate and private sector, accompanied by an almost total neglect of developing an intra-regional network at the wider civil society level, has resulted in a weak or non existent sense of community in the Asia-Pacific (Webber 2001) As a consequence, APEC has failed to provide much needed political legitimacy for the wider regional liberal economic project.

Although the rivalry between an Asian integration project and APEC is not new (see Higgott and Stubbs, 1995), policy elites in Asia do seem to be reconsidering the benefits of regionalism without the Caucasians. In particular the American opposition to an "Asian Monetary Fund" sewed the seeds for a further polarisation of the relationship between the Anglo-Saxon and the Asian APEC countries (Dieter and Higgott 1998, 51) and bolstered the development of a dialogue between Southeast and Northeast Asia. The initial Japanese proposal of an Asian Monetary Fund (AMF) ${ }^{10}$ would, in all probability, not have avoided the Asian crisis entirely, but we will never know what contribution to limiting the magnitude of

9 Kahler argues that the resistance of Asian policy makers to strengthen APEC by employing legalised structures was caused by their fear of American dominance (Kahler 2000, p. 568). 
downturn it might have made. ${ }^{11}$ But the crisis in Korea, which started after the AMF proposal was rejected by the Americans and which was primarily a liquidity crisis, not a solvency crisis, might have been avoided.

The existing regional integration projects in Southeast Asia and the Pacific have not fared well during the recent crises. They have neither contributed to the prevention of the crises nor have they made the resolution any easier. The challenge for the Asian policy community since then is to develop new forms of regionalism that address the deficiencies of conventional regionalism.

The Asian crisis of 1997/98 also underlined the weaknesses of the informal approach to regional integration in which both ASEAN and APEC had previously taken pride. The 'ASEAN way', characterised by personalised co-operation, remains prone to retrenchment and spillback (Rüland 2000, 445). APEC too suffers from its low key approach. Before the crisis, protagonists of APEC were happy to declare it as a new type of regionalismeconomic integration without bureaucratic institutions. The European Union in general and the Commission in particular were the models to be avoided (see Higgott 1995 and 1997b). The Asian crisis demonstrated the limits of non-fomralised institutional commitment.

\section{Beyond Conventional Integration Theory}

Since the early 1960s, theorising about regionalism has been influenced by Bela Balassa's approach to the subject. Balassa $(1961,1987)$ suggested that regional integration should evolve in five distinct steps:

(1) free trade area,

(2) customs union,

(3) common market,

(4) economic and monetary union

(5) and finally political union.

But this typology was first articulated well over 40 years ago and in a very different historical context. In the 1960 s tariffs, as the principal barriers to trade, were much more important

10 Another AMF, the "Arab Monetary Fund", has existed since 1976.

11 The then Japanese Finance Minister Hiroshi Mitsuzuka outlined the plans for an AMF during a meeting on 21 September 1997. The meeting was attended by twelve countries: Japan, China, Hong Kong, Korea, Malaysia, Indonesia, the Philippines, Thailand, Australia, Singapore and New Zealand. The USA and the IMF attended the 
than today. Financial flows across the boundaries of national economies were much less important. Most countries, including the United States, used capital controls to ensure that the fixed exchange rates of the Bretton Woods system were not undermined by high inflows or outflows of capital. ${ }^{12}$ Trade integration offered an answer to the economic goals of many countries. They could prepare for the world market or, in a more radical but popular version, they could dissociate their economies from the global economy, which was obviously easier for a group than for individual countries.

But that was then. Today, the most problematic aspect of Balassa's approach is that provides no link of the monetary policies and the financial sectors of the participating economies on the first three levels of integration. In an era of globalisation and liberalisation, reflected in growing capital flows, this constitutes a major theoretical and policy deficiency. Furthermore, the introduction of an economic and monetary union is a change of tune from the first three steps, where the emphasis lay on trade.

One may argue that this approach was modified when implemented in Europe. The creation of the European Monetary System in 1979 added a strong element of monetary co-operation. Although Europe took on this element to its own integration process, the need for intensive co-operation with regard to monetary and financial stability in an integration project is reflected neither in the conventional theory of regionalism nor in projects currently implemented outside of Europe.

\section{(2) A Theory of Monetary Regionalism}

In contrast to conventional regionalism, monetary regionalism aims directly at levels four and five of Balassa's integration concept. Monetary regionalism wants to contribute to the stability of currencies and financial markets in a region without having to formalise trade links. Like conventional regionalism, it requires the willingness of participating states to enter a process which, if successfully implemented, will lead at least to the creation of a common currency. Therefore, the willingness to give up a part of what has been understood as a central element of a nation's sovereignty and independence, in particular the ability to issue

meeting with observer status. These observers opposed the Japanese plan; subsequently, the meeting was adjourned without a decision (Wang 2000, p. 207).

12 The US reintroduced capital controls in the early 1960s, when rising imports, the cost of the Vietnam War and high capital inflows threatened the fixed exchange rate regime. 
one's own currency, is central to monetary regionalism. Such an integration process could be organised in four steps as set out in Table 1.

These proposals do not represent a complete list of measures that could be taken within a regional integration project that intends to improve its immunity against financial crisis. Nor do all measures have to be implemented simultaneously. However, they represent a set of policies that aim at both profound regional integration and provide instant benefits for the participating economies. The concept of monetary regionalism as well as the advantages and disadvantages of the individual measures are considered below.

Level 1: Regional Liquidity Fund The central measure to be taken at level 1 is the creation of a public regional liquidity fund. This is an attempt to provide a regional safety net if a crisis hits. The countries participating have to earmark a part of their foreign reserves for a liquidity pool. A participating central bank will, in such a system, not only be able to use its own reserves, but also those of the other central banks. Technically, such a liquidity fund has to be a swap agreement: A participating central bank will have the right to swap domestic currency for foreign currency. 
Table 1: Key components of monetary regionalism

\begin{tabular}{|c|c|c|c|c|}
\hline & $\begin{array}{l}\text { Level 1: } \\
\text { Regional } \\
\text { Liquidity Fund }\end{array}$ & $\begin{array}{l}\text { Level 2: } \\
\text { Regional } \\
\text { Monetary } \\
\text { System }\end{array}$ & $\begin{array}{l}\text { Level 3: } \\
\text { Economic and } \\
\text { Monetary Union }\end{array}$ & $\begin{array}{l}\text { Level 4: } \\
\text { Political Union }\end{array}$ \\
\hline $\begin{array}{l}\text { Main } \\
\text { Component }\end{array}$ & $\begin{array}{l}\text { Creation of a public } \\
\text { regional liquidity } \\
\text { fund }\end{array}$ & $\begin{array}{l}\text { Introduction of a } \\
\text { regional monetary } \\
\text { system with } \\
\text { exchange rate } \\
\text { bands }\end{array}$ & $\begin{array}{l}\text { Permanent fixing of } \\
\text { exchange rates and } \\
\text { creation of a single } \\
\text { currency }\end{array}$ & $\begin{array}{l}\text { Creation of a } \\
\text { political union, } \\
\text { national political } \\
\text { systems continue to } \\
\text { exist and cover } \\
\text { most issues }\end{array}$ \\
\hline $\begin{array}{l}\text { Political } \\
\text { Measures }\end{array}$ & $\begin{array}{l}\text { Creation of a forum } \\
\text { for the central } \\
\text { banks of the region, } \\
\text { i.e. a regional } \\
\text { monetary } \\
\text { committee }\end{array}$ & $\begin{array}{l}\text { Regular meetings } \\
\text { of the regional } \\
\text { monetary } \\
\text { committee }\end{array}$ & $\begin{array}{l}\text { Creation of } \\
\text { common political } \\
\text { institutions, } \\
\text { establishment of a } \\
\text { Regional Central } \\
\text { Bank }\end{array}$ & $\begin{array}{l}\text { Creation of } \\
\text { supranational } \\
\text { institutions in } \\
\text { some, defined areas }\end{array}$ \\
\hline $\begin{array}{l}\text { Additional } \\
\text { Compo- } \\
\text { nents (crisis } \\
\text { manage- } \\
\text { ment) }\end{array}$ & $\begin{array}{l}\text { Creation of a } \\
\text { private liquidity } \\
\text { fund }\end{array}$ & $\begin{array}{l}\text { Expansion of } \\
\text { coverage of } \\
\text { existing regional } \\
\text { liquidity funds }\end{array}$ & & \\
\hline \multirow[t]{2}{*}{$\begin{array}{l}\text { Additional } \\
\text { Compo- } \\
\text { nents (crisis } \\
\text { prevention) }\end{array}$} & $\begin{array}{l}\text { Implementation of } \\
\text { Universal Debt- } \\
\text { Rollover Options } \\
\text { with a Penalty } \\
\text { (UDROP) }\end{array}$ & & & \\
\hline & $\begin{array}{l}\text { Capital controls of } \\
\text { the individual } \\
\text { countries, in } \\
\text { particular on } \\
\text { inflows, may } \\
\text { continue to exist }\end{array}$ & & $\begin{array}{l}\text { Phasing out of } \\
\text { capital controls }\end{array}$ & \\
\hline $\begin{array}{l}\text { Trade } \\
\text { Compo- } \\
\text { nents }\end{array}$ & & $\begin{array}{l}\text { Facilitation of } \\
\text { regional trade by } \\
\text { harmonising norms } \\
\text { and standards }\end{array}$ & Customs Union & $\begin{array}{l}\text { Free movement of } \\
\text { labour }\end{array}$ \\
\hline $\begin{array}{l}\text { Macroeco- } \\
\text { nomic } \\
\text { Policy }\end{array}$ & $\begin{array}{l}\text { Joint monitoring of } \\
\text { monetary and fiscal } \\
\text { policy; regional } \\
\text { surveillance of } \\
\text { financial markets }\end{array}$ & $\begin{array}{l}\text { Co-ordination and } \\
\text { harmonisation of } \\
\text { monetary policy, in } \\
\text { particular interest } \\
\text { rate policy as well } \\
\text { as fiscal policy, in } \\
\text { particular on debt } \\
\text { levels }\end{array}$ & & \\
\hline
\end{tabular}


This is, of course, a measure that requires substantial political will on the part of the participating countries. A factor limiting the required confidence is a ceiling on the percentage of foreign reserves that participating central banks are willing to earmark for regional use. For the first level of monetary regionalism, it seems adequate to limit the funds to ten or twenty per cent of foreign reserves. Conditions for the use of other countries' reserves would have to be strict. To avoid the abuse of the regional liquidity fund, interest would have to be paid and the interest rate would have to be set at a punitive level. Also, the regional credit line should only be available for a short period, e.g. three months up to six months.

The advantages of a public regional liquidity fund are substantial:

- A central bank using the other central banks' reserves has a much higher chance to act as a lender of last resort for the domestic financial sector, thus developing the ability to limit the consequences of a credit crisis. ${ }^{13}$ Using the regional reserves, a central bank gains leverage. This aspect is particularly relevant for economies that have partly or completely abandoned capital controls, because the use of international financial markets and of loans denominated in foreign currency limit the ability of central banks to act as lender of last resort.

- Being able to use the region's foreign reserves reduces the need for the individual central bank to maintain costly foreign reserves. The costs of holding reserves should not be underestimated. Typically, reserves of foreign currency are held in highly liquid instruments that earn very small returns. It is realistic to assume real returns of not more than two percent per year. If this capital would be invested, a conservative estimate would expect a real return of 12 percent annually. Thus, every billion of reserves held cost a developing country 100 million a year. A country like China, with reserves of over $\$ 300$ billion, loses at least $\$ 30$ billion due to its high reserve holdings. ${ }^{14}$ However, even if the individual members of the integration scheme reduce their holdings of foreign exchange, the whole group will have to maintain substantial reserves.

13 Sussangkarn argues that the provision of liquidity may indeed increase the panic of investors, who may see problems of solvency rather that of liquidity (Sussangkarn 2000, p. 20). However, even such a panic will not be prolonged, provided fundamentals are strong,

14 In the case of China, this represents more than $2.8 \%$ of GDP. 
- The provision of liquidity in a region would avoid it having to go (automatically) to the IMF. This might be the biggest political advantage of a regional fund.

- Although a regional liquidity fund would only be activated in the event of a crisis, it would encourage participating central banks to engage in permanent monitoring of economic developments in the region. Joint regional surveillance of financial markets could begin.

In order to be able to establish a purposeful regional liquidity fund, the participating central banks would have to possess significant foreign reserves. Taking into consideration that initially probably not more than 10 or 20 per cent of the reserves will be available for a regional liquidity fund, this constitutes a major obstacles for monetary regionalism in some parts of the world. In East Asia, however (as Table 2 indicates), this presents less of a problem.

One might suggest that the creation of a regional liquidity fund is primarily targeted towards stabilising exchange rates. This is not the case. The main purpose of such a fund is initially limited to providing sufficient liquidity for banks and corporations that, due to a sudden swing in market sentiment, may be confronted with an inability to rollover existing debt denominated in foreign currency.

Whereas the measures to prevent a crisis from developing, discussed below, are no radical departure from the current system, a regional liquidity fund is. It is directly aimed at challenging the IMF monopoly on crisis management. In the event of a crisis, there would be no, or at least less, need to negotiate with the IMF.

Moreover, a public regional liquidity fund could be accompanied by private regional liquidity funds. The idea is that private banks and other financial intermediaries create a system which provides liquidity in the event of a banking crisis. When a bank gets into trouble, the other banks have to supply fresh money up to the initially agreed limit. ${ }^{15}$ As a principle, the private regional liquidity fund should operate as a first line of defence for banks. The creation of this system of two liquidity funds would be a significant step forward for a regional integration project. It would both provide powerful instruments to limit financial crises and generate the

15 In Germany, such a system has been in place since a major banking crisis in 1974. The "LiquiditätsKonsortialbank", Liko-Bank in short, is currently available to 136 participating banks. Private funds are augmented by funds from the German Central Bank. An expansion of the Liko-Bank to cover the Eurozone is being discussed. 
functional basis for further integration. This becomes particularly evident when monitoring of financial markets and banking supervision are included in the integration process.

The provision of a public regional liquidity fund ought to be accompanied by two monitoring bodies, a regional monetary committee and a regional banking supervision system. Committing foreign reserves of a country's central bank, even if it is limited to a certain percentage, is not just a bookkeeper's exercise, but a genuine expression of confidence. In order to build further on this mutual trust, a regional monetary committee is of vital importance. Central bankers could meet frequently to discuss developments in the financial sector and in foreign exchange markets.

In the discussion of a new financial architecture, the surveillance of financial markets has recently played an important role. It does also feature in our proposed scheme for monetary regionalism. However, one should not overestimate the scope of surveillance: It is not a substitute for a liquidity fund and other hard measures to stop a crisis from spreading. As the collapse of the American Long-Term Capital Management hedge fund (LTCM) in 1998 has shown, even well regulated markets can be subject to dramatic bankruptcies. If doubts remained after LTCM, which could hide part of its liabilities due to its registration in an offshore-financial centre, the collapse of the giant energy company Enron in late 2001 underlined that surveillance of highly developed financial markets is difficult, in particular when cronyism and corruption cannot be ruled out. Another example of the limits of surveillance can be found in Berlin: The Bankgesellschaft Berlin, owned by the state government, would without fresh capital have collapsed under its debt in summer 2001. This would have been the largest bank failure of post-war Germany, and banking supervision did only see the trouble when it was too late already.

Although in the proposed structure of level 1 the fixing of exchange rates is not envisaged, the regional monetary committee could prepare this step. The establishment of a regional monetary committee would also contribute to the creation of "intra-regional policy networks", which enables policy makers to deepen their knowledge of their partners in the region.

Similarly, banking supervision could be advanced to the regional level. Apart from the beneficial effect this could have for the integration process, national banking supervision seems to have become more obsolete in the age of banks operating in global financial 
markets. However, the installation of a regional body for banking supervision will not end the need for national banking supervision immediately.

In addition to the creation of a regional liquidity fund, measures to reduce the likeliness of financial crises are a vital element of monetary regionalism. The aim here is to force the private sector to consider the risks associated with lending and borrowing. Without strict accompanying measures, a large regional liquidity fund could cause moral hazard: Borrowers and lenders could assume that they would eventually be bailed out and therefore they might not properly evaluate risk in the first place.

Kim, Ryou and Wang have argued that the regional liquidity fund ought to be implemented with high interest rates in order to avoid moral hazard:

"To address the moral hazard problem, a penalty rate should be charged to the lending under the facility. If the interest rate is too low and there is no string of conditionality, borrowers may not have a sufficient incentive to be more careful next time (Kim, Ryou and Wang 2000, p. 41).

However, high interest rates are not sufficient. The rates would be charged for swap arrangements between central banks. Private borrowers and lenders would not be directly affected by high interest rates. Rather, high cost of borrowing affects governments and their central banks. A solution for this problem has to address the risk of moral hazard directly, i.e. at the level of borrower and lender.

Rollover options on loans from abroad could be one solution to this problem. Universal DebtRollover Options with a Penalty (UDROP), suggested by Anne Sibert and William Buiter in 1999, are an instrument which can be exercised upon maturity of a loan. The use of the option results in an extension of the credit, e.g. an additional 3 or 6 months. The option has a price, which will have to be set before the deal is done. The cost of the option in effect works like a tax on borrowing abroad. Consequently, borrowing domestically becomes cheaper compared to foreign loans. Both parties would have to agree on the price. As a result, they would have to consider the risk associated with the loan. Since financial crises tend to be characterised by panic and by a lack of sober evaluation, the implementation of UDROP would have several advantages (see Dieter 2000). The main ones are:

- In this situation of financial crisis, debtors gain valuable time. Liquidity problems caused by panic will be less likely. 
- The necessity to find a price for the option will increase the readiness to thoroughly evaluate the credit risk.

- The pressure on the exchange rate of a country affected by a credit crisis can be reduced significantly.

- The implementation of UDROP requires neither a global consensus nor the approval from the IMF. While they can be implemented by individual countries, they are well suited for monetary regionalism: The collective introduction of UDROP will strengthen the bargaining position of the participating countries and will reduce the risk of being cut off from international financial markets.

By contrast, the disadvantages of UDROP, in particular when implemented by a group of economies, are quite limited. The main disadvantages are that UDROP can only provide help in the event of a liquidity crisis, not in a solvency crisis. In other words, a bank or company facing bankruptcy will eventually not be saved. Also, UDROP increase the cost of borrowing and consequently deteriorate the competitive position of the debtor relative to companies borrowing without UDROP.

On the first level of monetary regionalism, just like in conventional forms of regionalism, the economies of the participating countries are quite likely to be heterogeneous. Taking the experiences of the first wave of regional integration in the 1960s into consideration, it seems necessary to provide measures for the weaker countries for self-protection. A main element would be the permission to continue the use of capital controls. In particular, countries should be allowed to limit the inflow of capital and to tie the inflow to certain conditions, e.g. favouring long-term loans over short-term loans. Also, taxes on short-term inflows, a policy successfully implemented by Chile in the 1990s, ought to be possible on the first level. ${ }^{16}$

The establishment of formal schemes to facilitate trade is not necessarily part of the level 1 . The reason for excluding trade is mainly political: The creation of a free trade area or customs union can be misinterpreted as the formation of a trade bloc and consequently can be used by policy makers in other countries to justify import restrictions. These notions are particularly

16 Technically, Chile imposed an Unremunerated Reserve Requirement (URR): A certain percentage of loans from abroad had to be deposited interest-free with the Chilean Central Bank. For a detailed review see Massad 1998 and Nadal-De Simone/Sorsa 1999. 
relevant for economies producing high surpluses in their trade accounts over longer periods of time, i.e. East Asian countries. ${ }^{17}$

Macroeconomic policy does not have to be co-ordinated and harmonised on level 1, but institutions should be created that permit the joint monitoring of macroeconomic developments. Such a step not only is an important precondition for the introduction of a monetary union, but also contributes to the creation of intra-regional policy networks.

Level 2: Regional Monetary System. The second step should be characterised by further preparation for monetary union. The introduction of a regional monetary system, with exchange rate bands, enables the participating economies to gain macroeconomic stability. The advantage of this system over a system with permanently fixed rates is obvious, it permits adjustments of exchange rates. ${ }^{18}$

Finding the appropriate exchange rates and useful exchange rate bands obviously is not an easy task. If the bands are too broad, the benefits from such a scheme are limited. Exporters and importers in such an arrangement with wide bands would still have to hedge their receipts from transactions in foreign currency. Therefore, exchange rate bands wider than say 10 per cent might be more symbolic than functional. On the other hand, if a narrow exchange rate band is chosen, for example $\pm 2 \%$, the risk of markets testing those bands quickly and successfully seems to be quite high.

After the experience with the European Monetary System, which operated successfully for more than a decade but partly collapsed in 1992, a regional monetary system may have lost some of its appeal. However, this system has to be evaluated in comparison with the other plausible alternatives and in different regional contexts. Countries may either opt for completely flexible exchange rates or hard pegs in the form of currency boards. In the aftermath of the Asian crisis and the Brazilian crisis, many influential economists were

17 Ravenhill argues that this is a major concern in East Asia: "The fear that the institutionalization of a discriminatory East Asian grouping might trigger a global trade war in which Asian economies would ultimately be the major victims still worries decision-makers in many Asian capitals" (Ravenhill 2000, p. 330). 18 Without discussing this issue in detail, it appears that in Asia there is no room for a currency system built around one individual currency, i.e. the Japanese Yen (Wang 2000). The main reasons are: Firstly, the monetary policy of the Japanese central bank lacks the transparency and cohesion that are necessary to achieve the status of a widely accepted reserve currency. Secondly, neither China nor other countries in East Asia would agree to a leading role for the Japanese central bank. 
stressing that only two viable exchange rate regimes existed. This so called bipolar view gained prominence. ${ }^{19}$

Howver, neither of these two alternatives is without great disadvantages. Flexible rates seem to be the easiest system. Central banks just watch the fluctuations without stabilising them. But flexible rates are a major obstacle for an expansion of international or intra-regional trade. Importers and exporters do not have a solid basis to calculate future receipts. This can partly be overcome by hedging, but hedging is a costly insurance. Needless to say, the providers of this type of insurance, i.e. big banks, regard flexible rates as the best exchange rate system. Furthermore, flexible rates in small, open economies are an easy target of speculative attacks and, in the event of major swings of the exchange rate, macroeconomic instability can be the consequence.

A currency board on the other hand leaves the central bank with very little room for manoeuvre. The exchange rate is fixed vis-à-vis an anchor currency, and domestic money supply is determined by the amount of foreign reserves a central bank holds. Although this system offers an alternative for economies previously plagued by very high inflation and very volatile exchange rates, it is no cure for the majority of developing countries and emerging economies. One of the reasons for this is that finding a suitable anchor currency is much more difficult than it appears at first. Due to the volatility of exchange rates between Dollar, Euro and Yen a currency board only transmits those fluctuations. A currency tied to the US-Dollar, for instance, would currently be a problem for an economy which exports substantially to the Eurozone.

The collapse of the currency board in Argentina has underlined the weaknesses of this exchange rate regime. The country successfully managed to overcome the legacy of the hyperinflation of the $1980 \mathrm{~s}$, but it is paying a very high price for this achievement. As a consequence of the crash of the currency board, Argentineans have lost the trust in their financial system, and it is hard to envisage that confidence in the soundness of the national financial market will be rebuild in the medium term. The repercussions of the collapsed currency board will be a burden for many years. Since neither corner solution is an attractive option, enhanced regional co-operation for the stabilisation of exchange rates is perhaps the only plausible alternative.

19 See for instance Fischer 2001. 
The establishment of a regional monetary system will have to be accompanied by an intensification of the co-operation by monetary authorities. Although separate currencies continue to exist, the intensity of communication between central bankers would have to be improved and regular meetings of the regional monetary committee appear to be useful. The press coverage of these meetings could be used to raise the awareness of citizens in the region with regard to the implementation of the integration process. When monetary co-operation is intensified and the coverage of the existing regional liquidity fund has been expanded, the additional measures taken for crisis prevention can gradually be phased out.

Trade facilitation could start to play a greater role at level 2. However, the establishment of a free trade area is not suggested: Firstly, because of the undesired administrative costs, secondly, because of the potential political vulnerability caused by formal trade regimes: The creation of a free trade area can be interpreted as a protectionist measure. Despite these reservations, trade facilitation may be implemented. Especially the harmonisation of norms and standards could make a valuable contribution to the integration process.

In preparation for level 3, the economic and monetary union, monetary and fiscal policy will have to be harmonised. Although the experience of the Eurozone offers no blueprint that can directly be applied elsewhere, the criteria used in the process leading to the creation of the Eurozone have a certain plausibility. These have been:

- the level of existing public debt shall not exceed 60 per cent of GDP,

- new public debt has to be less than 3 per cent of GDP,

- the inflation rate should not be more than 1.5 per cent above the inflation rate in the three countries with the lowest inflation,

- the economies must have participated successfully, i.e. without adjustments, in the European Monetary System for at least two years,

- long-term interest rates should not be more than 2.0 per cent above the respective rates for the three best economies.

The plausibility of those criteria is sufficient. The combination of measures to evaluate public debt and inflation is simple enough to be workable. It includes criteria primarily determined by markets (exchange rate, long-term interest rate), not by official declaration. At the same 
time, the treaty provides some flexibility regarding these five criteria, in particular concerning the level of public debt, which may be above 60 per cent provided it is sufficiently fast approaching the 60 per cent criterion. On the other hand, the levels set have no specific explanation. For instance, why a level of 60 per cent was chosen is unclear. Nevertheless, the combination of factors considered assures a certain level of macroeconomic stability. ${ }^{20}$

Level 3: Economic and Monetary Union. The creation of an economic and monetary union is more than a simple step for an integration project. Clearly, major conditions have to be met before such a far-reaching measure can be implemented. At the same time, an economic and monetary union has disadvantages that participating countries may not wish to accept. In particular the inability to react to differing economic developments within the union with exchange rate adjustments can be seen as a major disadvantage of this level of regional integration.

However, an economic and monetary union clearly has major advantages over a regional monetary system. Transaction costs are permanently reduced and competition within the union is strengthened. Above all, exchange rate adjustments within the union are no longer a threat. Companies do no longer have to pay for hedging against exchange rate volatility.

With regard to trade, once the third level of integration is reached at least a customs union is required. Although theoretically trade within a project of monetary regionalism could still be subject to tariffs and other forms of trade restrictions, one of the aims of a common currency, i.e. the strengthening of competition, could not be achieved fully. A free trade area, however, should not be implemented, because of the need to administer certificates of origin: Trade would not be facilitated as much as in a customs union. At the same time, restrictions on migration could remain in place. In particular in areas with greatly differing levels of development, the introduction of the freedom of employees to move within the union ought to be limited to the last and final level of integration. This is particularly so in East Asia where it is clearly a very sensitive political issue.

Level 4: Political Union. The completion of the integration process, the creation of a political union, will not require many additional measures with regard to economic policy, but rather

20 The Mercosur countries have been inspired by the European approach. Following the treaty of Maastricht, in December 2000 they have agreed on ceilings for inflation ( 5 per cent maximum), public debt (40 per cent of GDP maximum) and new public borrowing (3 per cent of GDP maximum). These goals shall be achieved from 2002 (Frankfurter Allgemeine Zeitung, 18 December 2000, p. 18). 
demand political integration. In particular, supranational political decision making bodies have to be founded. In most areas, economic policy integration will have been implemented on lower levels of integration. A deepening of the integration process could be the reduction of national tax systems in favour of a uniform union-wide tax system. But measures of that nature do not seem to be vital for the success of the political union. A certain variation of tax rates would not undermine the integration project.

The main benefit of the integration project continues to exist during the entire implementation phase: The region would gain independence and would be more immune to financial crises. The economic preconditions for such a scheme are high, and probably only in an East Asia monetary regionalism can be implemented successfully. Political obstacles will also have to be considered carefully before assessing the plausibility of monetary regionalism.

\section{The Evidence from Asia?}

The previous section offered an overview of the stages by which monetary regionalism could develop. It is the argument of this section that evidence of an emergence of monetary regionalism is indeed to be found in East Asia. The region-policy elite and wider community alike - perceives IMF policy throughout the late 1990s as humiliating and wrong. In the summer of 1997 the IMF together with the US government impeded the Japanese initiative to create an Asian liquidity fund. ${ }^{21}$ The Asian Monetary Fund (AMF as it would have been called) was explicitly to apply softer conditions than those of the IMF. The AMF's concept corresponded to being more a 'lender of last resort' than the IMF. Essentially, the AMF idea was about providing unconditional loans to overcome liquidity crises (Dieter/Higgott 1998).

By the end of 1999, the worst impacts of the Asian crisis was over and East Asian policy circles once again addressed the topic of more intensive regional co-operation. ${ }^{22}$ The regular ASEAN summits were expanded by the participation of Japan, China and South Korea, the new body being called ASEAN+3 (or APT). Since then, some steps in the search for a new monetary regionalism have been:

21 Rüland states that the proposal for an AMF was a joint initiative of ASEAN and Japan (Rüland 2000, p. 429).

22 Webber argues that external factors have driven the rise of ASEAN +3 more than internal causes, particularly the behaviour of the IMF and the US (see Webber 2001). 
- In December 1997, the first "East Asian Summit" (EAS) took place in Kuala Lumpur. Not surprisingly, monetary issues were discussed. ${ }^{23}$

- During the ASEAN+3 meeting in Manila in November 1999, the scope for regionalism in Southeast and East Asia was discussed. The summit chair, then Philippines President Joseph Estrada, told the news media the goals were a common market, monetary union and an East Asian Community (Financial Times, 29 November 1999, p. 4).

- Increasing numbers of Japanese observers advocate monetary cooperation in Asia. In an interview with the New Straits Times in January 2000, Eisuke Sakakibara, former state secretary of the Japanese finance ministry, for example spoke out for a co-operative monetary regime in East Asia (World Bank, Development News, 12 January 2000).

- $\quad$ During the fourth ASEAN finance ministers' conference in March 2000 plans for setting up a regional liquidity system were discussed (Frankfurter Allgemeine Zeitung, 29 March 2000; cf. the declaration of the ASEAN Finance Ministers www.asean.or.id).

- At the beginning of May 2000, Japan suggested a plan for a network of currency swaps, in effect a regional liquidity fund, to Asian finance ministers attending the annual meeting of the Asian Development Bank in Thailand. The idea was that Asian countries should be able to borrow from each other via short-term swaps of currency reserves (Financial Times, 6/7 May 2000, p. 9). ${ }^{24}$ The finance ministers of the ASEAN countries, China, Japan and South Korea reached an agreement in Chiang Mai, although major elements of the proposal still have to be finalised. ${ }^{25}$

- In September 2000 Thailand's then Deputy Prime Minister and future WTO-Secretary General, Supachai Panichpakdi, underlined the need for an Asian Liquidity Fund. Taking

23 China was urged to refrain from a devaluation of the Chinese currency, the yuan. The Chinese government agreed to maintain the old exchange rate ( Rüland 2000, p. 433).

24 Il Sakong, chairman of the Korean Institute for Global Economics, during the meeting in Chiang Mai underlined the need for a regional response: "We need to have some kind of defence mechanism. Since not much is expected to be done at the global level, something should be done at the regional level" (Financial Times, 6/7 May 2000, p. 9).

25 In the Chiang Mai meeting, the envisaged volume of the swap agreements was very limited. Thailand, Malaysia, Singapore, Indonesia and the Philippines discussed an expansion of their existing swap arrangements from \$ 200 million to $\$ 2$ billion (Financial Times, 8 May 2000, p. 10). Although such a step would not do harm, it clearly is too limited for an effective regional liquidity fund, which needs both Japan and China as contributing partners. On a point of historical note, this plan is similar to the one drawn up in the early 1960s by the G10 industrial nations as a way of addressing similar global monetary questions in the 1960s. 
US views on the future of the IMF into consideration ${ }^{26}$ he argued that IMF resources would be insufficient to cope with future crises.

- During the 2000 ASEAN+3-Meeting in Singapore, the Chiang Mai-initiative was reaffirmed. At the same time, the Chinese Prime Minister Zhu Rongji made a proposal for a free trade area between China and ASEAN, excluding Japan (Financial Times, 27 November 2000, p. 3).

- In January 2001 France and Japan tabled a joint paper during the meeting of ASEM finance minister in Kobe. The paper suggested that stable exchange rates and financial flows are reachable at a regional level. ${ }^{27}$

- In May 2001, the Chiang Mai-initiative was clarified during the annual meeting of the Asian Development Bank in Honolulu. The network of bilateral swap agreements was more precisely defined. Japan pledged to led up to \$ 3 Billion to Souith Korea, up to $\$ 2$ billion to Thailand and up to $\$ 1$ billion to Malaysia. However, it was decided that only 10 per cent of these sums will be available automatically. For sums above the 10 per cent level the approval of the IMF will be required.

The decision taken in Honolulu appears to be a major setback for monetary regionalism in East Asia. However, the need for IMF approval has been intepreted by some observers as a useful condition.

'These countries will only be able to use more than $10 \%$ of these sums with IMF approval - a key point which helps to allay fears about financial support for unwise policies' (Saker 2001).

This position would be more plausible if the IMF had implemented wise policies during the Asian crisis. This, however, has not been the case. The need to get IMF approval puts the entire project of a regional liquidity fund into question: Why create a separate credit facility if it cannot be used independently?

All this can seem speculative and theoretical. But there are good historical cum practical reasons not to view it in this way. Past crises have usually had a strong regional flavour and support packages, although organised by the international institutions, have invariably been

26 For a discussion see Williamson (2000).

27 The paper implicitly uses the approach of monetary regionalism. The paper is available in the internet (www.mof.go.jp/english/asem/aseme03e.htm). 
primarily under written by regional funds. A regional body to coordinate such packages in the future thus makes sense and, in effect, merely reflects reality on the ground. In so doing, it could also pay greater attention to crisis prevention, as opposed to crisis management, which has been the principle modus operandi in the past (see Rajan 2000 on this point).

Most important, the theory of monetary regionalism only makes sense in practice if a sufficient level of funding is available to underwrite such an enterprise. It could not be countenanced in the absence of a sufficient level of foreign reserves. But there is a demand and the funds to fill the demand are available in East Asia wher reserves are not only high, they are also regionally well distributed. The two largest economies, Japan and China, also have the largest reserves. In the event of a crisis, those two economies would make the highest contribution. Also, considering the high level of reserves, a regional liquidity fund is plausible even without using too high a percentage of the reserves of the participating central banks. The region has more foreign reserves than any other. Even without Taiwan, which alone enjoys reserves of more than US\$ 100 billion, the central banks of East Asia together have US\$ 1000 billion at their disposal. ${ }^{28}$

Table 2: Foreign reserves of East Asian economies

\begin{tabular}{|c|c|c|c|}
\hline Country & $\begin{array}{c}\text { Reserves in 2000 } \\
\text { (March) in billions } \\
\text { of US-Dollar }\end{array}$ & $\begin{array}{c}\text { Reserves in 2001 } \\
\text { in billions of US- } \\
\text { Dollar }\end{array}$ & $\begin{array}{c}20 \% \text { available for } \\
\text { a regional liquidity } \\
\text { fund }\end{array}$ \\
\hline China & 156.8 & $206.5(\mathrm{Oct})$ & 35.6 \\
\hline Hong Kong & 96.3 & $111.2(\mathrm{Dec})$ & 22.9 \\
\hline Indonesia & 26.3 & $27.3(\mathrm{Nov})$ & 4.5 \\
\hline Malaysia & 30.6 & $29.8(\mathrm{Oct})$ & 5.4 \\
\hline Philippines & 12.9 & $12.2(\mathrm{Oct})$ & 2.4 \\
\hline Singapore & 74.3 & $75.8(\mathrm{Dec})$ & 16.0 \\
\hline South Korea & 74.0 & $101.6(\mathrm{Nov})$ & 18.9 \\
\hline Thailand & 34.1 & $32.6(\mathrm{Nov})$ & 6.3 \\
\hline Japan & 305,5 & $402,0(\mathrm{Dec})$ & 75.5 \\
\cline { 1 - 3 } & &
\end{tabular}

28 Between early 2000 and late 2001 alone, reserves in the APT countries have risen by over $\$ 180$ billion, reflecting the political will to create defence mechanisms against a repetition of the Asian crisis. 


\begin{tabular}{|c|c|c|c|}
\hline Total & $\underline{\mathbf{8 1 0 . 8}}$ & $\underline{\mathbf{9 9 9 . 0}}$ & $\underline{\mathbf{1 9 9 . 8}}$ \\
\hline Taiwan & 103.5 & 110.1 & 22.0 \\
\hline Total inc. Taiwan & $\underline{\mathbf{9 1 4 . 3}}$ & $\underline{\mathbf{1 1 0 9 . 1}}$ & $\underline{\mathbf{2 2 1 . 8}}$ \\
\hline
\end{tabular}

Sources: The Economist, 4 March 2000; The Economist, 12 January 2002; Brunei Currency Board, Japanese Ministry of Finance (www.mof.go.jp/english).

The forward looking and inclusive character of the project is underlined by China's participation. Today, China has no need for additional liquidity from the region. Together with Hong Kong's monetary authority, China's central bank has reserves of over US\$ 300 billion, much more than enough for an economy that enjoys the additional safety net of comprehensive capital controls. Interestingly, Xiang Huajcheng, China's finance minister, has emphasised less the relevance of the project for China, but rather for the region. He supported the project 'because it would contribute to the economic and financial stability of the region' (Financial Times, 8 May 2000, p. 10; emphasis added).

\section{The Growth of Bilateral Free Trade Agreements:}

In contrast to the theoretical speculation about the prospects for monetary regionalism in East Asia we can juxtapose a growing interest in bilateral strategies for trade expansion. This, according to several sources in the region, is a reflection on the ineffectivensss of APEC and the hiatus in the WTO. There can be little doubt that this hiatus, not simply since Seattle, but basically since the completion of the Uruguay Round, has revived interest in bilateral agreements. From January 1995 to December 1999 alone 69 new regional trade agreements were notified to the WTO, including previously existing arrangements 113 were in power at the end of 1999 (Sapir 2000, p. 1135). These figures do not include regional agreements that were still in negotiation stages and had not yet been notified to the WTO.

The degree to which Bilateral Free Trade Agreements or other forms of PTAs are sub-optimal in comparison to the multilateral freeing of trade are well explained in the theoretical economic literature and need not be rehearsed here. The important question is: Why does sound economic theory not automatically find it way in to good public policy? The answer, which most economic theorists miss, is that good economic theory is very often bad politics. 
Policy makers are prepared to engage in uncoordinated bilateral decision-making, often leading to inferior outcomes (especially asymmetrical bargains for the weaker states) because it creates the illusion of being in control of one's own policy processes and policy choices. The fear of being shut out of other agreements in times of low esteem for, and trust in, the multilateral trading system sees governments developing bilateral strategies of their own. As Bhagwati recently noted, this is a global phenomena and one in which the world's major economic power, the US, is currently showing a form of unaccustomed leadership the world could well do without. (Bhagwati 2001).

Given the interest of the Bush Administration and the new United States Trade Representative Robert Zeollick in particular (see Financial Times, 6 March 2001, 10) in the Free Trade Agreement of the America's (itself a massive PTA) it is no surprise that there has also been an increase in the tempo of bilateral negotiations in other parts of the world, including East Asia (see Table 3). Whether it is a bilateral deal between Australia and China, Singapore and the USA, Japan and Singapore, China and ASEAN or Vietnam and the United States, there is a similar rhetoric that underpins the arguments advanced by trade ministers. It runs thus: notwithstanding that the bilateral deals are a 'second class option when compared with the benefits of multilateralism in the current climate they seem the only way forward. ${ }^{29}$

Notwithstanding the global nature of this trend, other region-specific reasons lie behind it in East Asia. At one level, bilateral trade arrangements are felt to give regional policy elites greater control over their own national trade policies, reflecting a view that their influence over deliberations within the context of the WTO are not always as significant as they would wish. To this extent, they are a statement of sovereignty. They are also a reflection of the decreasing salience of ASEAN as an economic organisation, if not necessarily a political organisation. But, given the historical success of GATT/WTO in reducing tariffs and to a lesser extent non tariff barriers, the benefits from regional free trade agreements, it should be noted, are much less significant than they used to be.

But perhaps more importantly, industry leaders in the region (those de facto agents of marketled economic integration, see Higgott 1997c) are acutely aware of the degree to which manufacturing is now more global than regional. Building regional trade blocs in an era of globalisation is deemed in many quarters to be no longer relevant. As the head of the 
Philippine Federation of Industries noted: 'If you are not global you are dead' (Far Eastern Economic Review, 9, December 1999, p. 22).

In sum, the argument presented here is not that East Asia is eschewing regionalism in favour of either globalism or bilateralism. No states ever pursue purely one-dimensional trade policy, or indeed foreign policy in general. Rather it is the core argument of the paper that we are seeing the emergence of a new regionalism in Asia that exhibits three over-lapping and complex trends: 
Table 3: Bi- and Multilateral Free Trade Agreements in the Asia-Pacific at the beginning of 2002

\begin{tabular}{|c|c|}
\hline $\begin{array}{l}\text { FTAs formally } \\
\text { proposed and } \\
\text { studied }\end{array}$ & $\begin{array}{l}\text { ASEAN-Australia-New Zealand } \\
\text { Australia-Japan } \\
\text { Australia-South Korea } \\
\text { Australia-Thailand } \\
\text { Australia-USA } \\
\text { Canada-Japan } \\
\text { Canada-Singapore } \\
\text { Chile-Japan } \\
\text { Chile-Singapore } \\
\text { Japan-Mexico } \\
\text { Japan-New Zealand } \\
\text { Japan-South Korea } \\
\text { New Zealand-South Korea } \\
\text { New Zealand-Thailand } \\
\text { New Zealand-USA } \\
\text { South Korea-Thailand } \\
\text { South Korea-USA } \\
\text { Taiwan-USA }\end{array}$ \\
\hline $\begin{array}{l}\text { FTAs currently } \\
\text { negotiated }\end{array}$ & $\begin{array}{l}\text { ASEAN-China } \\
\text { Australia-Singapore } \\
\text { Chile-New Zealand } \\
\text { Chile-South Korea } \\
\text { Chile-USA } \\
\text { Hong Kong-New Zealand } \\
\text { Japan-Singapore } \\
\text { Mexico-Singapore } \\
\text { Mexico-South Korea } \\
\text { Singapore-USA }\end{array}$ \\
\hline $\begin{array}{l}\text { FTAs ratified and } \\
\text { implemented }\end{array}$ & $\begin{array}{l}\text { ASEAN Free Trade Area (AFTA) } \\
\text { Australia-New Zealand (CER) } \\
\text { Australia-Papua New Guinea (PATCA) } \\
\text { Canada-Chile } \\
\text { Canada-Mexico-USA (NAFTA) } \\
\text { Chile-Mexico } \\
\text { New Zealand-Singapore } \\
\text { Vietnam-USA (Trade agreement) }\end{array}$ \\
\hline
\end{tabular}


(1) an interest in monetary regionalism arising from the desire that has emerged, since the financial crises of the late 1990s, to combat financial volatility;

(2) an interest in developing bilateral trade initiatives within the context of the multilateral system. This process being largely at the expense of the APEC style open regionalism project of the 1990s;

(3) the emergence of a voice of region beyond that of the sub-regions--Southeast and Northeast Asia on the one hand-but more restricted than that of the Pacific as a mega region on the other. In keeping with an early argument made by Higgott and Stubbs (1995), the voice of region that is emerging in the domain of the global political economy is an 'East Asian' one. This argument has recently been picked up by Fred Bergsten and others. ${ }^{30}$ It is discussed below.

\section{(3) The Politics of the 'New' Asian Regionalism}

Irrespective of the causal explanations of the Asian financial crises of the late $1990 \mathrm{~s},{ }^{31}$ the closing years of the twentieth century have convinced Asian regional policy elites that, in Bergsten words, '...they no longer want to be in thrall to Washington or the West when trouble hits in the future'. Bergsten, with Jo Stiglitz, is rare amongst influential American observers in recognising the degree to which East Asian states felt that they were 'both let down and put upon by the West' in the crisis (2000:20). For many in the west, the Asian financial crises was but an opportunity to displace the 'Asian developmental statist approach with the Anglo-American model. Triumphalism and schadenfreude was rampant (see Zuckerman 1998).

But in Asia, there was a strong feeling that the international institutions did more to exacerbate the problems than solve them (for discussions see Bello 1998; Wade and Veneroso 1998). It is in this context that the regional initiatives since 1997 need to be located. This is especially the case with the dialogue about monetary regionalism. It is also the case with the development of a process of East Asia wide summitry in Asean +3 - or APT - that

30 see Bergsten 2000; Webber 2001; Rapkin 2001. 
commenced in 1997. The APT reflects a membership of Asian states mirroring Dr Mahathir's proposal for an EAEG that was strongly opposed by the Caucasian members of APEC, especially the USA, in the early 1990s (see Higgott and Stubbs 1995).

Since the initial 1997 meeting of the APT Heads of State, annual summits have been installed and regular policy meetings (especially of finance ministers, central bank governors and relevant senior officials) convened to hammer out details of enhanced economic cooperation at the level of the East Asian region. The APT may have been kick-started by a financial crisis, but also salient has been the gradual change in thinking about regionalism in Asia. Central to these changes have been a reappraisal of the utility and future of APEC and ASEAN and the development of the Asia Europe Meeting process (ASEM). ASEM has acted as a stimulus to the growth of the APT. If disappointing for its overall advance of substantive Asia-Europe relations, ASEM has nevertheless prompted APT states to develop regular mechanisms for extensive policy coordination prior ASEM meetings (Lay Hwee, 2000; Higgott, 2000).

APT and an AMF (by any other name) in particular, it is hoped in the region, would give Asia added voice in the determining the shape of the new international institutional architecture- $\mathrm{a}$ point not lost on the US in its opposition to the AMF proposal in 1997. The US clearly understood that, despite stated best intentions, an AMF would not long be likely to adhere IMF policy prescriptions if they appeared at odds with an Asian view of how the world economy should be organised. Thus a successful AMF would, ipso facto, contest an 'AngloAmerican' view on global economic organisation (see Higgott and Rhodes, 2000).

Importantly, the political rhetoric surrounding the discussion over monetary regionalism is not emerging in an economic vacuum. There is a stronger economic logic to the APT than is often acknowledged from outside, especially amongst the key protagonists of APEC keen to establish it as the rational definition of region. Recent data and analyses demonstrate the growing economic interdependence of the APT region. Cross border trade between states of the APT as a percentage of total average external trade (at $44 \%$ ) might be less than for APEC (at 70\%), but it compares well with NAFTA (at 46\%) (Webber 2001, Table 1). As Webber notes.

31 This is not the place to rehearse the competing explanations of the origins of the Asian financial crises. The arguments are reviewed in a vast array of literature. See inter alia, Wade and Veneroso 1998; Higgott 1998; Dieter 1998 and 1999; Beeson et al. 1999; Pempel 1999; Jomo 1999; Bello 1998. 
'To the extent that this creates corresponding potential market gains from integration and business pressure for regional integration, East Asia should have no less 'integration potential' than North America “ (Webber 2001).

One might add that East Asia consequently has a higher potential for integration than ASEAN. This view is supported in a recent study conducted at the Asian Development Bank (see Das 2001). Such dfata notwithstandning, the traditional emphasis on trade concentrations, so dear to the heart of APEC booster is, we would argue, not as salient as a growing interest in the coordination of monetary policy in East Asian. In fact, recent studies of the economic prerequisites for monetary integration have found that an ASEAN+3 style grouping is in a not much less significantly inferior position than was the EU several years prior to the Maastricht Treaty (Bayoumi and Eichengreen 1997; Bayoumi, Eichengreen and Mauro 1999).

Of course when state interests are dissaggregated, different members of the APT have different agendas in pushing the relationship. For the key ASEAN states, prospects of stronger relations with two of the world's major economic powers (Japan and China) — for all their current economic limitations - is self-evident. Moreover, it is not only Dr Mahathir who has long recognised that influence over the international institututional architecture depends on being part of a much larger group reflecting a collective position. ASEAN leaders like Lee Kuan Yew, and major opinion formers in the region such as Tommy Koh and Noordin Sopiee (see Koh 1999: 8) regularly express similar views

But more important than the views of the individual ASEAN partners to the longer-term evolution of the APT is the position of the major powers, notably Japan and China from within the APT and the US from outside of it. For example, Japan has come under more and more pressure, both for internal and external reasons over the last decade to sort itself out. Its economy today is, for a variety of reasons, in a cul-de-sac, saddled with public debt, deflation, bad loans and a lack of consumer confidence that will, sooner or later, have to be addressed. $^{32}$ This economic reality according to Peter Katzenstein (2000:360) has changed East Asia's perception of Japan. Today, the fear of too much influence of Japan might have been replaced by the fear of too little power to deal with its own economic problems.

However, such problems notwithstanding, there is considerable evidence of a Japanese agenda to see greater regional monetary cooperation, maybe even an AMF, although this is an 
institution that presently dare not speak its name. Since the time of the abortive attempt to create an AMF in 1997, Japan has consistently developed initiative and backed the activities of others in the region wishing to advance policies that might lead to greater monetary regionalism.

Indeed, on close inspection, Japan has played a greater leadership role on these issues over the last few years than most of its critics will concede. ${ }^{33}$ Yet still to be tested, is the degree of Japanese will to resist a full assault by the US on Asia's attempts to smuggle in an AMF style organisation through the back door. The Honolulu decision to require IMF consent for the use of the bilateral swap arrangements represents a major set back. The major problems in the organisation of the region in years to come resides in the relationship between the US and Japan on the one hand and between Japan and China on the other. As David Rapkin has so powerfully argued, both the US and Japan are at a situation where neither can push through its own vision of the policy future for the region in the absence of acquiescence from the other. As Rapkin shows in his study of the US veto of the first AMF initiative and the Japanese veto of US desires for early sectoral trade liberalisation within APEC, the two allies have 'blocking power' over each other (Rapkin 2001).

While a leading role for Japan in an Asian integration project might be accepted by smaller countries, China is likely to be less acquiescent. The resolution of the Sino-Japanese relationship thus represents as big a challenge for Asian regionalism as does the relationship between the US and Japan. According to Webber, the past, the present and the future continue to strain the relationship. The past because Japan has neither apologised in an accepted manner for the atrocities committed during World war II and the occupation of China and other countries in the region ${ }^{34}$ nor has Japanese society come to terms with their role in the region. ${ }^{35}$ At present there is also an element of systemic competition between Japan and China. But most importantly the future casts a shadow over the relationship. If current economic trends continue it is not difficult to see the day when, in terms of the material, and indeed intellectual capacity for leadership, China can eclipse Japan in the region.

33 These initiatives, such as the Miyazawa agreement cannot be discussed in detail here. But see Higgott 1998 for an early account and for a comprehensive discussion see the forthcoming $\mathrm{PhD}$ thesis by Shigeko Hiyashi, Japanese Foreign Economic Policy and the Idea of an Asian Monetary Fund, Warwick University, Department of Politics and International Studies, 2002.

34 The Chinese annoyance with Japan's reluctance to accept its responsibility for the past has been fuelled again in 2001 (Chu 2001).

35 On Japan's ambivalent position--neither an integral part of the West nor of Asia--see Heberer 1997. 
Understandably, this development makes Japanese leaders more nervous than their counterparts in China. China may worry about contemporary Japanese economic power, but the Chinese can imagine a day when this gap will be much smaller than it is now. Japan conversely, can only speculate on what the decreasing asymmetry in the economic capabilities of the two countries implies for China's longer-term regional intentions in a range of other policy areas, especially the security domain. This view will only be partially assuaged by China's increasingly responsible regional citizen role in its strong support of the idea of an AMF style organisation.

We are thus faced with a paradox. The absence of acceptable or credible hegemonic power in East Asia remains a major obstacle to the successful implementation of the monetary regionalism project at the same time as it adds force to the idea of, and need for, collective action problem solving via a body like the APT. It is this paradox that gives ASEAN its strategic role (at least in the short run) in nurturing the APT dialogue. In so doing, playing the intermediary role between the two major regional powers provides ASEAN with a raison d'être at a time when its institutional viability was under pressure from the financial crisis. ${ }^{36}$ This role, however, can be only a stop-gap measure. ASEAN has none of the material power of the larger players. Moreover, if something like an AMF were to develop, it would need strong conditionality procedures attached to the financial support it offered. This means rules. But 'ASEAN way' diplomacy, built on consensus decision-making, remains inimical to the development of strong rule driven conditionality. It would thus be necessary to move beyond the consensus element in ASEAN way decision making.

This may not prove as difficult as might be at first assumed. There are signs that this approach, so important in earlier times, may have outlived its usefulness. Some modification is not impossible. All Asian policy makers are looking to a regional agreement that allows them to eschew hard line IMF medicines of the kind that were metered out at various stages in the $20^{\text {th }}$ century. Smaller states of the region in particular--for it is they, almost invariably, that will be relying on the support of the financially richer states--may be more willing to accept looser conditionality, but conditionality none the less, if it emanates from a regional institution in which they feel like stakeholders and participants in the process. In their relationship with the major international institutions to-date, most Asian states have seen

36 There was little common cause within ASEAN as to how to respond the crises of 1997-8. The economically healthiest state, Singapore, exhibited little affinity for the troubles besetting its partners. For a discussion see Narine 2000. 
themselves simply as 'rule takers' and never as 'rule makers'. These seemingly cosmetic differences are much more significant, albeit more intangible, than can ever be caught in any economic model of financial reform.

\section{Conclusion}

This paper is speculative. But hopefully it is not naive. It has proposed a theoretical approach to the way regionalism in East Asia might develop over the near to mid term future. But the paper, unlike much economic theory, acknowledges the manner in which politics can derail theory. Thus it has located this exercise in theory building within a realistic empirical context. Events on the ground in Asia, particularly the wishes of the regional policy elites for mechanisms to cope with financial volatility, are driving this process. In the wake of the financial crises of the late 1990s, and in the absence of cast iron guarantees emanating from the international financial architecture, policy makers in the region aspire more to collective problem solving at the regional level than in the past. It is this changing context that makes the kind of theoretical exercise developed in this paper germane.

Amongst both economic theorists and specialist of the international relations of the Asia Pacific, this paper will surely find critics. Economists will clearly resist the argument that stages in the established theory of regional integration (what we might call the Balassian model) might be jumped. But such resistance can only be sustained in a static, ahistorical, context. The argument advanced here is that is an evolutionary model that takes account of the changing dynamics of economic interdependence under conditions of globalisation; especially the increased importance of financial markets at the expense of markets in manufactures that dominated at the time that the Balassian model was developed.

By contrast, a traditional realist scholar in international relations would undoubtedly suggest that the argument under-estimates 'balance of power' and security questions in the region. This is not the case. Nowhere does the paper suggest that these issues are not central to the contemporary international relations of East Asia. But since the end of the Vietnam War, the regional policy communities have proved capable of desegregating economic and security concerns. They have certainly proved more capable of this than some of the darker predictions of realists scholars would have had us believe throughout the closing decades of the $20^{\text {th }}$ century. 
Of course, as in any specific historical circumstance, if diplomacy fails and a stable or balanced security environment brakes down, all other areas of policy are inevitably adversely affected. However, an assumption of this paper, and one that is not easily refuted, is that Asian policy makers are not conducting their international relations underwritten by the principle that conflict over contested issues in the politico-security domain is at some stage inevitable. This is not to suggest that conflicts of a localised or wider nature are unthinkable, nor that security planning is not a major aspect of national policies within the region. Clearly they are. Activity in the security domain over the last decade suggests that all states of the region are well aware of the tensions and difficult issues in need of resolution, be they on the Korean Peninsula, across the straits of Taiwan, in the South China Sea, on the Indonesian archipelago or wherever. But there is no assumption that these cannot be dealt with by diplomacy.

For all its limitations, the multilateral security dialogue in the region developed dramatically, and positively in the last decade of the twentieth century. There is no reason why this trend should not continue. Rather than ignore the security issues, or suggest that there is no linkage between them and economic questions, this paper argues that it is quite plausible to see regional policy communities pursuing co-operative initiatives in the domains of finance and trade. In short, they are quite capable of playing a multi-dimensional diplomatic game.

Consider for example the relationship between Beijing and Tokyo - a central relationship in any discussion of the future of the region. While Beijing has benefited from the developments of the late $20^{\text {th }}$ and early $21^{\text {st }}$ century, the key question to be resolved in coming years is the degree to which increased economic ties between Japan and China will help alleviate the climate of mutual distrust in other domains and allow them to cooperate in the enhancement of regional economic policy coordination. This is not an easy question to answer. Analysis can be of two types.

We can advance determinist arguments (pace Kenneth Waltz 1979) of a structural realist type, from which we would assume conflict of a destabilising nature at a later stage. Or, we can make judgements on the basis of what has been observed in the economic diplomacy of the region over the last twenty years. From this standpoint, we would attribute much more theoretical strength to the role of agency and the influence of actors in the policy process. As such, and notwithstanding that the 1994 Chinese devaluation of the renminbi was a significant factor in the Asian financial crisis, the general view in the region is that China has 
behaved responsibly and cooperatively in efforts to mitigate the prospects of further financial volatility (Wang 2000: 210).

Similarly, that there is still a large amount of distrust of China's motives amongst other sections of the East Asian regional policy elite is not at issue. The real question is over the degree to which this mistrust can be mitigated as a problematic factor in the development of monetary regionalism and the consolidation of the APT. It is around such questions that the prospects for East Asian co-operation via the APT in general, and the development of monetary regionalism (by the creation of an AMF or some such like institution) will be determined.

This paper has argued that the financial crises of the closing decades of the 1990s may have been a sufficiently traumatic learning experience, especially for some of the weaker state policy making elites, to create a recognition of a need to shed a little sovereignty, in order to preserve wider state building capacity and regional stability. Vulnerability to financial market volatility is now seen as one of the major challenges to policy autonomy. It may be this sense of vulnerability that is the key to the further development of regional collective action in the monetary sphere. 


\section{References}

Aggarval, Vinod K.; Ravenhill, John (2001): Undermining the WTO: The Case Against 'Open Sectoralism'. Asia Pacific Issues, February 2001.

Apel, Emmanuel (1998): European Monetary Integration. London: Routledge.

Balassa, Bela (1961): The Theory of Economic Integration. Homewood (Illinois): Richard Irwin.

Balassa, Bela (1987): Economic Integration. In: Eatwell, John; Milgate, Murray; Newman, Peter (eds.): The New Palgrave. A Dictionary of Economics. Vol. 2 (E to J), London and Basingstoke: Macmillan, pp. 43-47.

Bayoumi, T. and Eichengreen, Barry (1997): Optimum Currency Areas and Exchange Rate Variability: Theory and Evidence. In: Cohen, B??? (ed.): Research Frontiers in International Economics, Princeton: Princeton University Press, pp. 143-184.

Bayoumi, T.; Eichengreen, Barry; Mauro, P. (1999): On Regional Monetary Arrangements in ASEAN. Conference on Exchange Rate Arrangements in Asia, Tokyo, Asian Development Bank/Korean Institute of Economic Planning Conference, December.

Beeson et al. 1999 ????

Bello, Walden, (1998) 'East Asia: On the Eve of the Great Transformation? Review of International Political Economy, Vol. 5, No. 3, pp. ???

Bergsten, C. Fred (1999): America and Europe: Clash of the Titans? Foreign Affairs, Vol. 78, No. 2, pp. 20-34.

Bergsten, C. Fred (2000): East Asian Regionalism: Towards a Tripartite World. The Economist, 15 July 2000, pp.19-21.

Bhagwati, Jagdish (2001): A Costly Pursuit of Free Trade, The Financial Times, 6 March, p. 21.

Breslin, Shaun,Higgott, Richard (2000): Studying Regions: Learning from the Old, Constructing the New', New Political Economy, Vol. 5, No 3, pp. 333-352.

Camroux, David (2001): Die ASEAN vor dem Ende. Le Monde Diplomatique, Februar 2001, p. 7.

Chu, Guangyou (2001): Integrate to Meet the Challenges of Globalization. Paper presented at the First ASEM Roundtable on 'Globalization and Regional Responses', Seoul, 28-29 May 2001.

Das, Dilip K. (2001): Regional Trading Arrangements and the Global Economy: An Asia Pacific Perspective, Manila, Asian Development Bank, Economic Analysis and Research Division, January, 1-97. ?????

Dieter, Heribert (2001): Trends und Interdependenzen in der Weltwirtschaft. In: Hauchler, Ingomar; Messner, Dirk; Nuscheler, Franz (eds.): Globale Trends 2002. Frankfurt/Main: Fischer (forthcoming).

Dieter, Heribert (2000): Monetary Regionalism: Regional Integration without Financial Crises. Centre for the Study of Globalisation and Regionalisation (CSGR) Working Paper 52/00. 
Dieter, Heribert (1999): Die globalen Währungs- und Finanzmärkte nach der Asienkrise: Reformbedarf und politische Hemmnisse. INEF-Report 41/1999.

Dieter, Heribert (1998): Die Asienkrise: Ursachen, Konsequenzen und die Politik des Internationalen Währungsfonds. Marburg: Metropolis Verlag.

Dieter, Heribert; Higgott, Richard (2001): Ostasiens Weg in eine Währungsunion. Internationale Politik, Vol. 56, No. 4, pp. 45-50.

Dieter, Heribert; Higgott, Richard (2000): The New Monetary Regionalism: The East Asian Financial Caucus Takes Shape, The Financial Times, 12 August.

Dieter, Heribert; Higgott, Richard (1998): Verlierer Japan, Gewinner China? Außenpolitische Konsequenzen der Asienkrise. Internationale Politik, Vol. 53, No. 10, pp. 45-52.

Eichengreen, Barry (2000): Vom Goldstandard zum Euro. Die Geschichte des internationalen Währungssystems. Berlin: Klaus Wagenbach Verlag.

Fischer, Stanley (2001): Exchange Rate Regimes: Is the Bipolar View Correct? January 2001, www.imf.org/external/np/speeches/2001/010601a.htm .

George-Mulgan, Aurelia (2000): A Setting Sun? Foreign Affairs, July/August 2000, pp. 4052.

Harris, Stuart (2000): The Regional Response in Asia-Pacific and its Global Implications. The Pacific Review, Vol. 13, No 4.

Heberer, Thomas (1997): Ostasien und der Westen: Globalisierung oder Regionalisierung? ASIEN, No. 63 (April), pp. 5-35.

Hew, Denis; Anthony, Mely C. (2000): ASEAN and ASEAN+3. NIRA Review, Autumn 2000, pp. 21-26.

Higgott, Richard (1994) APEC: A Sceptical View. In: Mack, Andrew; Ravenhill, John (eds.): Building Regional Institutions in the Asia Pacific. Boulder, Colorado: Lynn Reinner Press.

Higgott, Richard (1995): Economic Cooperation in Europe and Asia: A Preliminary Comparison. Journal of European Public Policy, Vol. 2, No. 3, pp. 361-383.

Higgott, Richard (1997a): Mondialisation et Gouvernance: l'Emergence du Niveau Regional. Politique Etrangere, 62 (2), pp. 277-292.

Higgott, Richard (1997b): Institutions, Identity and Social Learning in the International Political Economy of Regionalism: Asia and Europe Compared. Kokusai Seiji: Journal of the Japanese International Studies Association, 114, March, pp. 14-48.

Higgott, Richard (1997c): De Facto and De Jure Regionalism: The Double Discourse of Regionalism in the Pacific. Global Society, 11(2), pp. 165-183.

Higgott, Richard (1998): The Asian Financial Crisis: A Study in the International Politics of Resentment. New Political Economy, Vol. 3, No. 3, pp. 333-356.

Higgott, Richard (2000): ASEM and the Evolving World Order. Global Economic Review, 29 (1), pp. 21-52.

Higgott, Richard (2000): Contested Globalisation: New Normative Agendas. Review of International Studies, 26: 131-53.

Higgott, Richard (2002) 'Taming Economics, Emboldening International Relations: The 
Theory and Practice of International Politicsl economy in an Era of Globalisation', in Stephanie Lawson (ed) The New Agenda for International Relations, From Polarization to Globalisation in World Politics, Cambridge: Polity, 91-108

Higgott, Richard; Stubbs, Richard (1995): Competing Conceptions of Economic Regionalism: APEC versus EAEC in the Asia Pacific. Review of International Political Economy, 2 (3), pp. 549-568.

Higgott, Richard; Phillips, Nicola, (2000): Resisting Triumphalism and Convergence: The Limits of Liberalisation in Asia and Latin America. Review of International Studies, 26 (3), pp. 359-379.

Higgott, Richard ; Rhodes, Martin (2000): After the Crisis: Beyond Liberalisation in the Asia Pacific? The Pacific Review, 13 (1), pp. 1-19.

James, Harold (1996): International Monetary Cooperation since Bretton Woods. New York and Oxford: Oxford University Press.

Jomo (1999): ?????

Kahler, Miles (2000): Legalization as Strategy: The Asia-Pacific Case. International Organization, Vol. 54, No. 3, pp. 549-571.

Katzenstein, Peter (2000): Regionalism and Asia. New Political Economy, Vol. 5, No. 3, pp. 353-368.

Kim, Tae-Jun; Ryou, Jai-Won; Wang, Yunjong (2000): Regional Arrangements to Borrow: A Scheme for Preventing Future Asian Liquidity Crises. Korea Institute for International Economic Policy, Policy Analysis 00-01.

Koh, Tommy (1999): Progress Toward an East Asian Free Trade Area. International Herald Tribune, 14 December.

Lay Hwee, Yeo (2000): ASEM: Looking Forward, Looking Backward. Contemporary Southeast Asia, 22 (1), pp. 1-16.

Narain, Shaun (2000): ASEAN and the Idea of an Asian Monetary Fund: Institutional Uncertainty in the Asia Pacific. Mimeo.

Park, Yung Chul; Wang, Yunjong (2001) Reform of the International Financial System and Institutions in Light of the Asian Financial Crisis. UNCTAD/Harvard Kennedy School, Working Paper 2001, forthcoming.

Pempel (1999): ????

Rapkin, David P. (2001): The United States, Japan, and the power to block. The APEC and AMF cases. The Pacific Review, Vol. 14, No. 3, pp. 373-410.

Ravenhill, John (2000): APEC adrift: implications for economic regionalism in Asia and the Pacific. The Pacific Review, Vol. 13, No. 3, pp. 421-451.

Rüland, Jürgen (2000): ASEAN and the Asian crisis: theoretical implications and practical consequences for Southeast Asian regionalism. The Pacific Review, Vol. 13, No. 3 , pp. 421-451.

Saker, Neil (2001): The Foundations of Stability. The Far Eastern Economic Review, 24 May 2001, p. 55.

Sapir, André (2000): EC Regionalism at the Turn of the Millenium: Toward a new 
Paradigm? The World Economy, Vol. 23, No. 9, pp. 1135-1148.

Stiglitz, Joseph (2000): What I learned at the world economic crisis. The New Republic, 17.4.2000 (www.thenewrepublic.com).

Stubbs, Richard (2000): Signing on to liberalization: AFTA and the politics of regional economic cooperation. The Pacific Review, Vol. 13, No. 2, pp. 297-318.

Sussangkorn, Chalongphob (2000). A Framework for Regional Monetary Stabilization. NIRA Review, Autumn 2000, pp. 16-20.

Wade, Robert; Veneroso, Frank, (1998): The Asian Crisis: The High Debt Model vs the Wall Street-Treasury-IMF Complex. New Left Review, 228 (March-April), pp.????

Waltz, Kenneth (1979): Theory of International Politics. Waltham MA: Addison-Wesley.

Wang, Yunjong (2000): The Asian Financial Crisis and Its Aftermath. Do We Need a Regional Financial Arrangement? ASEAN Economic Bulletin, Vol. 17, No. 2, pp. 205-217.

Webber, Douglas (2001): Two Funerals and a Wedding? The Ups and Downs of Regionalism in East Asia and the Asia Pacific after the Asian crisis. The Pacific Review, Vol. 14, No. 3, pp. 339-372.

Williamson, John (2000): The Role of the IMF: A Guide to the Reports. Institute for Internationale Economics, Policy Briefs, No. 00-5. May 2000.

Zuckerman, Mortimer (1998): A Second American Century. Foreign Affairs, Vol. 73, No. 3, pp. 18-31. 